O. Butenko ${ }^{1}$, S. Gorelik ${ }^{1}$, A. Topchiy ${ }^{1}$, T. Bryzhachenko ${ }^{2}$

${ }^{1}$ National Aerospace University «Kharkiv Aviation Institute», Kharkiv, Ukraine

${ }^{2}$ Eastern Europe, advanced business events - BCI Aerospace, Toulouse, France

\title{
ASSESSMENT OF THE DYNAMICS OF ENVIRONMENTAL CHANGES IN EASTERN UKRAINE USING THE DATA OF THE EARTH SPACE MONITORING
}

\begin{abstract}
The main pollution factors that influence the change in the ecological state of the eastern territories of Ukraine bordering with occupied are analyzed. The dynamics of changes in the level of concentration of pollutants due to flooding of mines, river pollution and rupture of shells has been revealed. The use of the Monte Carlo method at the stage of mathematical modeling is justified to determine the trend of changes in the ecological state of the monitoring object, based on which cartographic pollution models are constructed. Preconditions are examined that demonstrate the need to develop a new method for increasing the efficiency of decision-making in order to reduce the negative impact of changes in the ecosystems of border regions as a result of the impact of hostilities. The possibility of solving the problem was investigated by the methods of mathematical analysis, mathematical statistics, methods of cartography and GIS analysis. Visualization of research results is presented in the form of cartographic models in accordance with different levels of concentration of pollutants.
\end{abstract}

Keywords: parameters, ecology; pollution; dynamics; data; methods.

\section{Introduction}

The military conflict in Eastern Ukraine has led to an increase in the concentration of pollutants in the soil, negative impact on the landscapes of surface and ground waters, vegetation and wildlife. The risks of accidents at industrial enterprises and infrastructure facilities that impair the quality of life and health of people have increased significantly. Conflicts that occur in industrially developed territories with a large number of environmentally hazardous enterprises, such as the territories of Donetsk and Luhansk regions, are especially dangerous for the environment.

As a priori information about the state of the environment in Eastern Ukraine received from official sources is limited, there arises need for additional complex assessment of the caused damage based on data provided by available information sources which allowed to form a vision of potential environmental impacts resulting from the conflict in the Donbas, and data from space monitoring of the Earth.

Thus, it is important to build cartographic models of pollution with visualization of results of the forecast modeling of their further distribution in the analyzed territory [1].

It should be noted that improving the efficiency of decision-making in order to prevent negative changes in the environmental condition of border areas due to military operations is possible only through a joint analysis of the factors that have the maximum impact on the change in the state of monitoring objects and determining the dynamics of changes in the level of pollutants concentration as a result of mines flooding, river pollution and shell explosions [2].

\section{The research objective.}

\section{Justification for choosing a modeling method}

There are many methods for analyzing monitoring results to assess the risks of emergencies due to changes in the environmental state of the observed territories. In the conditions of uncertainty caused by insufficient a priori information, there comes need to create a database of indirect thematic features. To do this, in accordance with each deciphering feature of the object must be supplied with attribute information on the specifics of the terrain and the results of hydro-geological studies, statistics, and other results of contact measurements. The result is quantitative assessment that determines the characteristics of each parameter (radiation contamination, flooding, methane emissions, soil contamination, water contamination, chemical contamination, debris contamination and inverted soil) in the form of graphs, diagrams and intermediate cartographic models.

Well-known scientific methods for describing and studying mass phenomena that allow (quantitative) numerical expression are usually used to evaluate such data sets. First of all, this applies to statistical modeling methods based on random variables (RB). The main difference between these methods is how to get data arrays, i.e. initial generation conditions. The main focus should be on analyzing the sensitivity of the initial data.

The initial data for modeling the degree of possible contamination of the studied territory depending on the change in the values of the initial data parameter vector are the results of applying the historical analogy method to obtain variable estimates of each of the indicators of all statistically possible pollution. For the initial processing of statistical material, as a rule, it is enough to use mathematical models of pollution, which are based on classical methods of probability theory and mathematical statistics. For mathematical modeling, different methods can be used that differ in the ways of generating sequences of initial data and the degree of their processing, as well as the subject area of application. However, when choosing methods, one needs to define clearly the specifics of the source data and the level of processing. For example, when using the Wang-Landau algorithm, which is an implementation of the entropic modeling method and is intended for calculating the density of the state of systems, it is necessary to take into consideration the fact that the generated random variables are interconnected by the law of entropy. Since we are talking about open systems that are capable of self- 
healing, that is, subject to the laws of synergetics, the concept of entropy takes on a slightly different meaning. First of all, this applies to the initial estimation of the values of the pollution parameter vector, when they are not interrelated. In this case, using the Wang-Landau algorithm for modeling environmental pollution at the primary stage, when the range of possible changes in each of the parameters is estimated, regardless of the degree of combinatorial influence of other factors, is not appropriate. It will be optimal to use it at another stage. In particular, we are talking about identifying the tendency of its further changes or determining the forecast horizon. In this case, the results of primary processing with the establishment of their relationship when changing the degree of influence on each other can be used as the initial data. It should be noted that since all further operations involve working with interval estimates obtained at the previous stage, it is recommended to use fuzzy set methods [3].

Using another widely used algorithm, Sampling, involves manipulating the initial sample of RV with a known modeling goal. Given the lack of complete data on the current state of environmental pollution, this method can only be used if there is a complete set of a priori data about the object of research. Having conducted similar analysis of other classical approaches to determining the level of pollution from environmental monitoring data, it was concluded that the Monte Carlo method is most appropriate. This method makes it possible to maximize the value of the data used in the model at all stages of processing, regardless of the degree of correlation between them. At the same time, the construction of the model begins with the definition of functional dependencies in a real open system. The result of this method is solutions determined on the basis of calculated quantitative indicators using the methods of probability theory and mathematical statistics in modeling.

\section{Assessment of the dynamics of changes in the economic condition of territories based on a comprehensive analysis of contact, statistical and remote data}

Assessment of changes in the environmental status of the Eastern Ukrainian border areas over the past five years requires a significant amount of initial contact data, which is not available in the non-controlled territory. Monitoring the contamination of territories caused by the military conflict requires systematic sampling of soil, air, and water from surface and underground sources on both sides. Unfortunately, systematic observations are only possible in the border area in the controlled Ukrainian territory. The lack of a priori information requires the use of Earth remote sensing (ERS) data.

According to the ERS data, it is possible to localize and identify potential sources of pollution and assess the extent of their impact on the ecological state of territories. Therefore, the combination of incomplete contact data with aerospace survey will allow to identify dangerous processes in ecosystems [4].

The presence of anthropogenic impact on landscapes associated with military actions is a feature of the analysis of aerospace imagery for these territories. For independent Ukraine, the belligerent (military) landscapes that have been formed in recent years are new, and require a more in-depth study of the extent of their impact on the environment. A belligerent landscape should be understood as a technogenic landscape formed as a result of military actions. These include the crater from the shell explosions, trenches, caponiers, etc.

Localization of belligerent landscapes in the East of Ukraine was carried out by determining their deciphering features (Table 1).

\section{Table 1- Deciphering features of belligerent landscapes}

\begin{tabular}{|c|c|c|c|}
\hline $\begin{array}{c}\text { Belliterative land- } \\
\text { scape (example) }\end{array}$ & Space image example & Direct decryption features & $\begin{array}{l}\text { Indirect decryption } \\
\text { features }\end{array}$ \\
\hline 1 & 2 & 3 & 4 \\
\hline $\begin{array}{l}\text { Funnels from } \\
\text { explosions of large- } \\
\text { caliber shells } \\
\text { (Saur-Mogila } \\
\text { district, Donetsk } \\
\text { region, 07/16/2014) }\end{array}$ & se & $\begin{array}{l}\text { Rounded shape, clear contour, light } \\
\text { gray photon predominates, dark gray } \\
\text { in the center, total diameter } 17-22 \mathrm{~m} \text {, } \\
\text { no shadows are observed. (the dark } \\
\text { gray photon of the surrounding field } \\
\text { is associated with its burnout after } \\
\text { the explosion of shells) }\end{array}$ & $\begin{array}{l}\text { As a rule, form significant } \\
\text { chaotic clusters; can be } \\
\text { located in any landscape. }\end{array}$ \\
\hline $\begin{array}{l}\text { Crater funnels } \\
\text { (Saur-Mogila } \\
\text { district, Donetsk } \\
\text { region, 07/02/2014) }\end{array}$ & $\begin{array}{cc}6 \\
\therefore \quad 6\end{array}$ & $\begin{array}{l}\text { Rounded shape, clear contour, } \\
\text { concentric-zonal structure: dark gray } \\
\text { photon in the center, light gray at the } \\
\text { edges total diameter } 10-13 \mathrm{~m} \text {, } \\
\text { diameter of the central part } 5-7 \mathrm{~m} \text {. } \\
\text { There are no shadows }\end{array}$ & $\begin{array}{l}\text { As a rule, form significant } \\
\text { chaotic clusters; can be } \\
\text { located in any landscape. } \\
\text { Similar to mounds, but differ } \\
\text { in photon (color), size and } \\
\text { texture. }\end{array}$ \\
\hline $\begin{array}{l}\text { Funnels from } \\
\text { explosions of small- } \\
\text { caliber shells } \\
\text { (Saur-Mogila } \\
\text { district, Donetsk } \\
\text { region } 07 / 16 / 2014 \text { ) }\end{array}$ & * * & $\begin{array}{c}\text { Rounded shape, clear contour, } \\
\text { concentric-zonal structure: dark gray } \\
\text { photon in the center, light gray at the } \\
\text { edges } \\
\text { total diameter } 6-11 \mathrm{~m} \text {, diameter of the } \\
\text { central part } 4-6 \mathrm{~m} \text {. There are no } \\
\text { shadows }\end{array}$ & $\begin{array}{l}\text { Often are more common than } \\
\text { funnels from larger calibers } \\
\text { (space image from } \\
08 / 15 / 2014)\end{array}$ \\
\hline
\end{tabular}




\begin{tabular}{|c|c|c|c|}
\hline 1 & 2 & 3 & 4 \\
\hline $\begin{array}{l}\text { Traces of the } \\
\text { movement of } \\
\text { military equipment } \\
\text { (Saur-Mogila } \\
\text { district, Donetsk } \\
\text { region 08/15/2014) }\end{array}$ & & $\begin{array}{l}\text { Linear, sinuous shapes with a clear } \\
\text { outline, photon light gray (usually } \\
\text { lighter than the surrounding } \\
\text { landscape), chaotic linear, chaotic } \\
\text { banded texture } \\
\text { There are no shadows }\end{array}$ & $\begin{array}{l}\text { Traces of the movement of } \\
\text { military equipment do not } \\
\text { coincide with the main } \\
\text { directions of the movement } \\
\text { of agricultural machinery. } \\
\text { The width of the strip } \\
\text { depends on the type of } \\
\text { military equipment }\end{array}$ \\
\hline $\begin{array}{l}\text { System of trenches } \\
\text { and dugouts } \\
\text { (District of } \\
\text { Sanzharovka, } \\
\text { temporarily } \\
\text { uncontrolled territory } \\
\text { of Ukraine } \\
05 / 06 / 2017 \text { ) }\end{array}$ & & $\begin{array}{l}\text { The trench system has the shape of a } \\
\text { broken line with clear contours. The } \\
\text { parapet has a light gray photon, and } \\
\text { the trench bottom is dark gray. } \\
\text { Dugouts are located at the places } \\
\text { where trenches are interrupted, or at } \\
\text { their ends, may have small } \\
\text { embankments. Lined, mesh texture }\end{array}$ & $\begin{array}{l}\text { A characteristic specific } \\
\text { pattern in the form of broken } \\
\text { lines with branches }\end{array}$ \\
\hline
\end{tabular}

\section{Mathematical simulation by the}

Monte Carlo method. Integration of heterogeneous multi-hour monitoring data

When forming a sample of initial data obtained as a result of the Earth space monitoring, an additional analysis of space images obtained by various survey systems was carried out. As a result, it was determined that the data obtained from the Landsat-7.8 and Sentinel-2 satellites provide sufficient decision-making accuracy to solve the problem. It can be explained by the fact that the satellite images obtained by this survey equipment are sufficiently informative, shareware, and contain the necessary amount of metadata [6].

In the Monte Carlo simulation of various levels of possible contamination and, as a consequence, the negative aftermaths caused by them, discrete random values were obtained, calculated using the formula:

$$
X=\left(\begin{array}{cccc}
x_{1} & x_{2} & \ldots & x_{n} \\
p_{1} & p_{2} & \ldots & p_{n}
\end{array}\right),
$$

where $X$ - discrete value; $x_{i}$-values of the $i$-th variables; $p_{i}$ - probability.

In this case, the implementation of this random variable is considered to be the degree of contamination in the area that is being studied, which can happen with an equal probability.

The mathematical expectation $M[X]$, which is known to be one of the main numerical characteristics of each random variable, was determined by the classical formula:

$$
M[X]=\sum_{i=1}^{n} x_{i} p_{i} .
$$

The variance $D[X]$ was also found with the use of the classical known formula for determining the numerical spread of the obtained values:

$$
D[X]=M\left[X^{2}\right]-(M[X])^{2} .
$$

In order to obtain an integrated assessment of the degree of contamination in the observed areas and to jointly analyze the space monitoring data and statistical data, the level of contamination concentration due to mine flooding was also calculated. For this purpose, the main sources of pollution were selected to be main indicators, which are radiation pollution, flooding, methane emissions, and soil pollution. For each pollution indicator for the Monte Carlo method, $M$ and D are calculated using the formulas (2) and (3) respectively. The results are presented in Table 1 . As it can be seen from the Table 1, all pollution parameters can be divided by the degree of pollution into three main groups - high, low and medium. Radiation pollution has the largest spread. Indicators of flooding, methane emissions, and soil pollution belong to the medium group of pollutants [7].

There were also calculations made for contamination of the ground as a result of shell explosions caused by military operations. As it took place with pollution that contributes to the flooding of mines, because the lack of a priori data, mathematical simulation was performed using the Monte Carlo method and the method of historical analysis. In this case, chemical contamination, debris contamination, and inverted soil were identified as main factors. For each pollution indicator, $\mathrm{M}$ and $\mathrm{D}$ were calculated using the Monte Carlo method by formulas (2) and (3), as in the previous case. The results are presented in Table 1. According to Table 1, the indicator of contamination of the turned-out soil belongs to a high group of polluting factors, and chemical pollution and debris pollution belong to medium and low, respectively [8]. The results of mathematical simulation are also presented in Table 2:

Table 2 - Results of mathematical simulation

\begin{tabular}{|c|c|c|c|c|c|c|c|c|}
\hline & $\begin{array}{c}\text { Radiation } \\
\text { contamination }\end{array}$ & Flooding & $\begin{array}{c}\text { Methane } \\
\text { emissions }\end{array}$ & $\begin{array}{c}\text { Soil conta- } \\
\text { mination }\end{array}$ & $\begin{array}{c}\text { Water conta- } \\
\text { mination }\end{array}$ & $\begin{array}{c}\text { Chemical } \\
\text { contamination }\end{array}$ & $\begin{array}{c}\text { Debris } \\
\text { contamination }\end{array}$ & $\begin{array}{c}\text { Inverted } \\
\text { soil }\end{array}$ \\
\hline $\mathrm{M}$ & 0,47 & 0,49 & 0,48 & 0,44 & 0,62 & 0,36 & 0,43 & 0,58 \\
\hline $\mathrm{D}$ & 0,1 & 0,04 & 0,09 & 0,05 & 0,07 & 0,06 & 0,02 & 0,1 \\
\hline
\end{tabular}


Analysis of the results presented in the table shows that the most dangerous types of pollution are water pollution due to mines flooding and inverted soil due to shell explosions.
According to the quantitative estimates obtained from the modeling, three main groups of pollution were formed - low, medium and high, which are shown in Fig. 1.

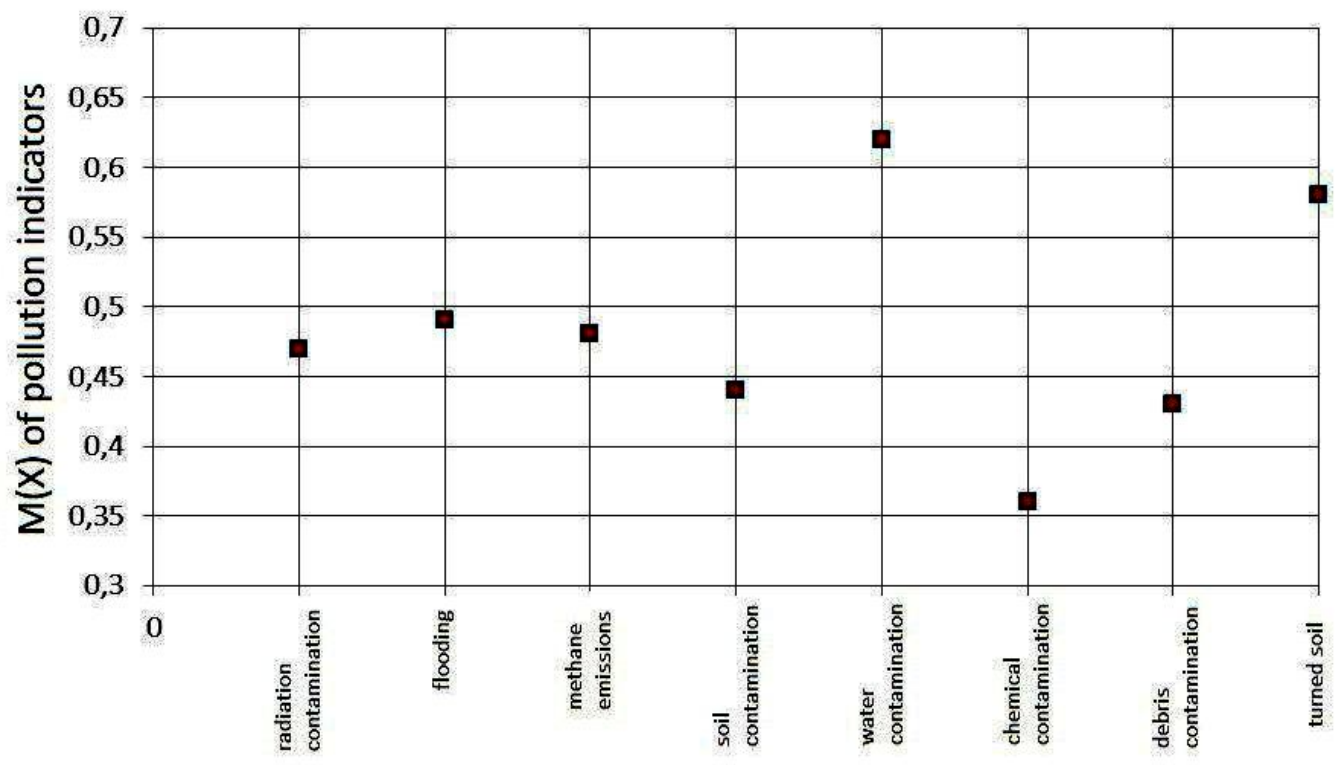

Fig. 1. Comprehensive assessment of contamination levels based on simulation results

As Fig. 1 shows, the largest indicators are water and soil contamination. From this we can conclude that water contamination due to the flooding of mines and turned-out soil due to the shells explosions are the most dangerous contamination factors in the territory of Eastern Ukraine. Based on the results of joint analysis

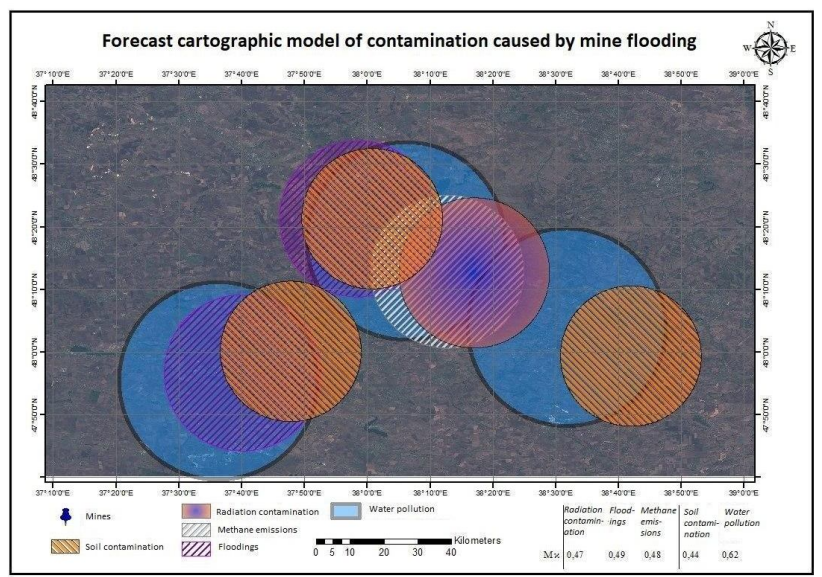

Fig. 2. Forecast cartographic model of contamination caused by mine flooding

As one can see in Fig. 2, water contamination has the largest coverage area, which is caused by the larger $\mathrm{M}(\mathrm{X})$ of this indicator, whereas radiation contamination has the smallest distribution on the territory of Eastern Ukraine. Fig. 3 shows the D (X) of pollution parameters such as inverted soil, debris contamination, and chemical contamination. According to the cartographic model, one can conclude that chemical contamination, resulted from debris contamination, has the highest dispersion indicators for each point of shell explosions.

The analysis of the constructed models allows us to come up with the conclusion that a large number of of simulation results, analysis of data obtained from open sources of information and space monitoring data, a forecast cartographic model for estimating the level of pollution due to flooding of mines and a forecast cartographic model of contamination caused by shell explosion was constructed (Fig. 2, 3).

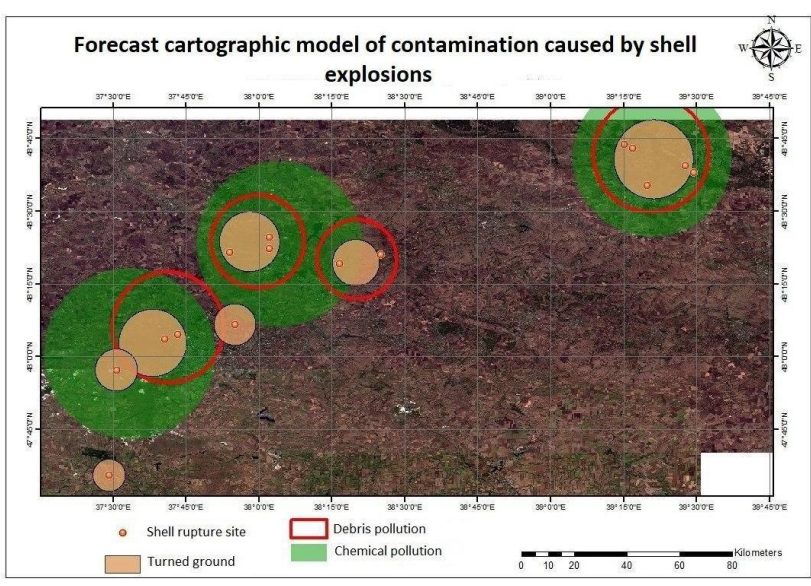

Fig. 3. Forecast cartographic model of contamination caused by shell explosions

polluting substances enter the rivers of the region due to the conduct of combat operations, disruption of enterprises working, and hydrological engineering structures.

In this regard, there appears need for additional environmental monitoring of the border areas of Eastern Ukraine in order to clarify assessments of the current state of the rivers in the frontline zone and determine how pollutants tend to spread to neighboring territories [9].

To analyze and build a cartographic model of pollution trends in rivers in the frontline zone of Eastern 
Ukraine, tabular data on average annual concentrations of pollutants are used [10].

In the article the sulphate contamination is considered. To do this, we use data from the water intake in the Volchya River, the channel of which passes through Donetsk, where pollutants enter.

The value of the content of the relative maximum permissible concentration (MPC) of sulphates at the initial point of water intake is known. Its excess value is 0.32 in relation to the MPC. According to the map of river flows, the volume of water for section $V_{1}$ is $12 \mathrm{~m}^{3} / \mathrm{s}$. The Mokri Yali River flows into the Volchya river, where $V_{2}=6 \mathrm{~m}^{3} / \mathrm{s}, C_{2}=0,1$. The calculation of the water volume at the confluence with the river is calculated by the formula:

$$
V_{\Sigma}=V_{1}+V_{2}=18 \mathrm{~m}^{3} / \mathrm{s}
$$

Next, we calculate the volume of the mixed substance in the resulting volume of water using the formula:

$$
C_{u}=\left(V_{1} \cdot C_{1}+V_{2} \cdot C_{2}\right) / V_{\Sigma} \approx 0,247 .
$$

Calculations for the next river that flows into the Kamenka River, where $V_{3}=5 \mathrm{~m}^{3} / \mathrm{s}$, and $C_{3}=0,3$ in relation to the MPC.

The final water volume $-23 \mathrm{~m}^{3} / \mathrm{s}$, the sulphate content $C_{u}=0,19$ in relation to the MPC.

To sum up, the pollution of the rivers of the adjacent area to the border areas showed a decrease in the number of pollutants depending on the territory of hostilities.

Based on the calculated quantitative characteristics, a cartographic model of the trend of river contamination development is constructed (Fig. 4).

Judging by Fig. 4 we can conclude that the degree of contamination of the Volchya River has the highest contamination index in the segment after the confluence of the Mokri Yaly, which is caused by summing contaminations of all rivers [11].

\section{Conclusion}

The analysis of the simulation results using the proposed algorithm for assessing the current environmental status of border areas showed that there was a sharp increase in the concentration of pollutants not only in soil, ground waters, but also in water surface objects.

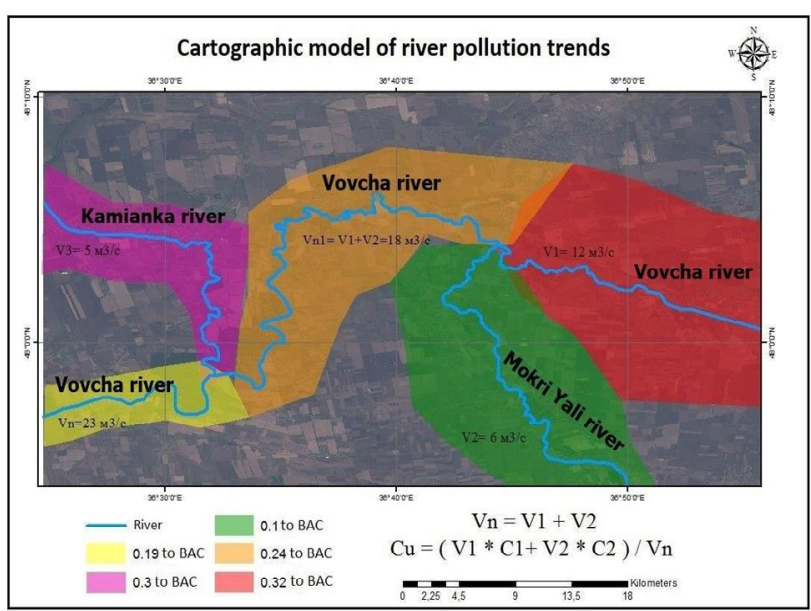

Fig. 4. Cartographic model of river pollution trends

These changes are directly connected with the beginning of the armed conflict in Eastern Ukraine.

The results of studies of the dynamics of changes in environmental pollution indicators over the entire time series allow us to conclude that water contamination caused by mines flooding has the greatest impact on the ecological state, as well as soil that was inverted by shell explosions.

A comparative analysis of indicators that characterize the pollution of the area adjacent to the occupied territories showed a decrease in the number of pollutants depending on the distance from the territory of the joint forces operation.

However, this process can be regarded as temporary. The forecast cartographic model, which is based on the Monte Carlo method, shows that there is a tendency of worsening of the environmental condition of adjacent territories and, as a result, all types of pollution will spread to "conditionally clean" areas of the territory, with all the negative consequences that follow.

To improve the accuracy of estimates of the current environmental state of monitoring objects and the construction of forecast models, a more complete set of data is necessary.

In conditions of uncertainty caused by insufficient quantity of objective information, the method presented in the article should be adapted to each object that is observed separately by using interval estimates while building logical-algebraic models.

\section{REFERENCES}

1. Yushchuk, A., Loik, I. and Yurtzaba Y. (2017), "Assessment of potential environmental risks as a result of an anti-terrorist operation", Organization for Security and Cooperation in Europe, p p. 45-51.

2. Gurevich, I.B., Zhuravlev, Yu.I. and Smetanin, Yu.G. (1999), "Construction of image algebras based on a descriptive approach", Reports of the 9-th All-Russian Conference "Mathematical Methods of Pattern Recognition", Moscow, pp. 33-36.

3. Scientific portal "Pollution year map" (2019), available to: http://texty.org.ua/water/

4. Bondar, O.I., Bairak, O.M. and Baranovskaya, V.E. (2016), National report on the state of the environment in Ukraine in 2014, Kyiv, pp. 52-85.

5. Maksimenko, E.A., Morozova, L.O., Alpatova, A.A., Gubanov, V.Y., Fastov, O.O. and Pogorelova, G.V. (2016), Regional report on the state of the environment in Lugansk region in 2016, Severodonetsk, 184 p.

6. Zhebrivsky P.I. (2017), Ecological passport of Donetsk region for 2016, 202 p.

7. Akhmadiev, F.G., Gabbasov, F.G., Ermolaeva, L.B. and Malanichev I.V. (2017), Numerical methods. Examples and tasks. Tutorial for the courses "Informatics" and "Computational Mathematics", KSASU, Kazan, $40 \mathrm{p}$.

8. Butenko, O.S. (2008), "Analysis of the possibility of predicting the spread of anomalies from space monitoring data", Information Processing Systems, No. 5 (72), pp. 38-44. 
9. Butenko, O.S. (2008), "A mechanism for constructing a short-term forecast based on a priori data", Control, navigation and communication systems, Central Research Institute of Navigation and Management, Issue 3 (7), Kyiv, pp. 37-40.

10. Al Khalili, A.M. (2002), "Classification of beligigerative landscapes of the north west r. r. Jordan", Bulletin of the Voronezh State University. Series: Geography. Geoecology, No. 1, pp. 59-64, available to: https://rucont.ru/efd/513820

11. Yakovlev, E.A., Yermakov, V.M.and Ulitsky O.A. (2012), "The environmental consequences of flooding of the Yunkom mine nuclear explosion chamber (Central Donbass)", Mineral resources of Ukraine, No. 1, pp. 38-44.

Надійшла (received) 12.12.2019

Прийнята до друку (accepted for publication) 29.01.2020

\section{ВідОмості ПРО АВТOPIB / AвOUT THE AUTHORS}

Бутенко Ольга Станіславівна - доктор технічних наук, професор, професор кафедри геоінформаційних технологій та космічного моніторингу Землі, Національний аерокосмічний університет ім. М. Є. Жуковського «ХАІ», Харків, Україна; Olga Butenko - doctor of Technical Sciences, professor, professor of the Department of Geoinformation technologies and space monitoring of the Earth, National aerospace university named Zhukovsky "KHAI", Kharkiv, Ukraine; e-mail: OS-B@,ukr.net; ORCID ID: http://orcid.org/0000-0001-9486-8633.

Горелік Станіслав Ігорович - кандидат технічних наук, доцент, завідувач кафедри геоінформаційних технологій та космічного моніторингу Землі, Національний аерокосмічний університет ім. М. Є. Жуковського «ХАІ», Харків, Україна;

Stanislav Gorelik - Candidate of Technical Sciences, Associate Professor, Head of the Department of Geoinformation technologies and space monitoring of the Earth, National aerospace university named Zhukovsky "KHAI", Kharkiv, Ukraine;

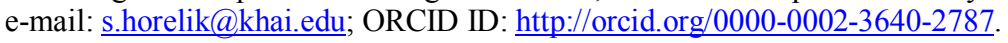

Топчий Анна - аспірантка кафедри геоінформаційних технологій та космічного моніторингу Землі, Національний аерокосмічний університет ім. М. Є. Жуковського «ХАI», Харків, Україна;

Anna Topchiy - graduate student of the Department of Geoinformation technologies and space monitoring of the Earth, National aerospace university named Zhukovsky "KHAI", Kharkiv, Ukraine; e-mail: annatop4y@gmail.com; ORCID ID: http://orcid.org/0000-0003-0448-4543.

Брижаченко Тетяна - торговий представник для Східної Європи, ВCI Aerospace, Тулуза, Франція;

Tetyana Bryzhachenko - Sales representative for Eastern Europe, advanced business events - BCI Aerospace, Toulouse, France;

e-mail: tbryzhachenko@advbe.com; ORCID ID: http://orcid.org/0000-0002-0459-2061.

\section{Оцінка динаміки змін екологічного стану східних територій України з використанням даних космічного моніторингу Землі \\ О. С. Бутенко, С. І. Горелік, А. Топчий, Т. Брижаченко}

Анотація. Проаналізовано основні фактори забруднення, що впливають на зміну екологічного стану прикордонних з окупованими східних територій України. Виявлено динаміка змін рівня концентрації забруднюючих речовин через підтоплення шахт, забруднення річок і розриву снарядів. Обгрунтовано використання методу МонтеКарло на етапі математичного моделювання для визначення тенденції змін екологічного стану об'єкта моніторингу, за результатами якого побудовані картографічні моделі забруднень. Розглянуто передумови, що показують необхідність розробки нового методу підвищення оперативності прийняття рішень для зниження негативного впливу змін в екосистемах прикордонних областей в слідстві впливу проведених бойових дій. Досліджено можливість для вирішення поставленого завдання методами математичного аналізу, математичної статистики, методами картографії та ГІС аналізу. Візуалізація результатів досліджень представлена у вигляді картографічних моделей відповідно до різного рівня концентрації забруднюючих речовин.

Кл юч ов і сл ов а : параметри; екологія; забруднення; динаміка; дані; методи.

\section{Оценка динамики изменений экологического состояния восточных территорий Украины с использованием данных космического мониторинга Земли \\ О. С. Бутенко, С. И. Горелик, А. Топчий, Т. Брыжаченко}

Аннотация. Проанализированы основные факторы загрязнения, влияющие на изменение экологического состояния приграничных с оккупированными восточными территориями Украины. Выявлена динамика изменений концентрации загрязняющих веществ из-за подтопления шахт, загрязнения рек и разрыва снарядов. Обосновано использование метода Монте-Карло на этапе математического моделирования для определения тенденции изменений экологического состояния объекта мониторинга, по результатам которого построены картографические модели загрязнений. Рассмотренные предпосылки показывают необходимость разработки нового метода повышения оперативности принятия решений для снижения негативного влияния изменений в экосистемах приграничных областей вследствие влияния проведенных боевых действий. Исследована возможность для решения поставленной задачи методами математического анализа, математической статистики, методами картографии и ГИС - анализа. Визуализация результатов исследований представлена в виде картографических моделей в соответствии с разным уровнем концентрации загрязняющих веществ.

Кл юче в ы е сл о в а : параметры; экология; загрязнение; динамика; данные; методы. 